$\triangle$ CTA NEOPHILOLOGICA

DOI: 10.4312/an.52.1-2.31-45
UDK: 821.163.4(497.6).09-31=111 Hemon A. UDK: 821.111(73).09-31Hemon A.

\title{
Tracing Transnationalism and Hybrid Identities in Aleksandar Hemon's The Making of Zombie Wars
}

\section{Nina Bostič Bishop}

\begin{abstract}
Transnationalism is a current reality as globalisation has accelerated by the never before experienced boost in the development of technology, transport and telecommunications. The modern era is also characterised by migrations - voluntary and involuntary, but most of today's transmigrants do not live the exilic lives once lived by migrants, longing for their homeland. Instead, they live in an in-between space - the host country and the homeland, where the mixing of cultures takes place. Although these zones have often been idolized in the recent literature, the lives of many transmigrants are characterised by feelings of loss, displacement and trauma. The present article attempts to map Bosnian-American author Aleksandar Hemon as a transnational diasporic writer by tracing the features of transnationalism in his life and his novel The Making of Zombie Wars. It will also position that several of the migrant characters in the novel are hybrid identities, battling the consequences of displacement, trauma and mobility, following the ideas of Homi Bhabha and Jopi Nyman. It will explore the processes as they occur in spaces in-between.
\end{abstract}

Keywords: Aleksandar Hemon, transnationalism, hybridity, diasporic literature, displacement, The Making of Zombie Wars 


\section{INTRODUCTION}

The present globalised world is characterised by voluntary and involuntary transnational migrations where cultural, linguistic and national boundaries are crossed, transforming the once homogenous cultures. These processes are reflected in contemporary diasporic writing that typically addresses the subjectivities formed in the process of transnational migrations, questioning the fixed ideas of home, identity and mobility while undergoing a transformation into new hybridised identities as constructed in Homi Bhabha's liminal Third Space, challenging the traditional movement from the centre to periphery.

\section{TRANSNATIONALISM}

Transnationalism as a term was first used by the radical social critic and multiculturalist, pacifist and anti-nationalist Randolph Bourne at the moment of emerging nationalism and American politics of isolationism in 1916. He used the term to counter-argue the then immigration policies of 'Americanisation', which aimed at eliminating enemies of the state by condemning the otherness of the immigrants, thereby attempting to strengthen the nationalist tendencies of the Anglo-Saxons, which would eventually bring solidarity amongst them (Vaughan 443). Bourne challenged these attitudes in an essay titled "Trans-National America", which he published in 1916 where he presented the idea of inter-cultural cooperation that would in his view also serve as a strategy for the survival of America's newest immigrants and in turn, reinforce the idea about the American identity which, according to Bourne, could not be explained by ignoring the immigrants since being an American to him meant to be a product of not only one, but many cultures (Resek 123). In Bourne's view American identity would comprise both, the ethnic and the modern and would therefore be signalled with a "hyphen" between the two nations. Although Bourne's idea of transnationalism appears to be somewhat idolised, it is related to the concept of hybrid identities as discussed below. On the other hand, while the contemporary concept of transnationalism emphasises its significance in battling essentialism, it also focuses on today's possibilities of transnational interaction, communication and mobility that are available in real time as Vertovec states and defines transnationalism as follows:

Transnationalism describes a condition in which, despite great distances and notwithstanding the presence of international borders (and all the laws and, regulations and national narratives they represent), certain kinds of relationships have been globally intensified and now take place paradoxically in a planet-spanning yet common - however virtual - arena of activity" (Vertovec 3). 
In addition to Vertovec, transmigration and transnationality were first employed by Nina Glick-Schiller, Linda Basch, Christina Blanc-Szanton, Ludger Pries, and Ulrich Beck who understood the need to address the new phenomenon of a transmigrant, who lives in two countries, cultures or even nations at the same time, surpassing the international boundaries and is active in developing and maintaining these relations across the social fields of the multiple homelands. Similarly, Sladja Blazan states that "To stress activity on the part of the migrant is programmatic, since taking actions and decision making are [the] main characteristics separating the transmigrant from the immigrant" and this agency on the part of the migrant is also notable in Hemon's life and in the life of some of his characters (Blazan 38).

\section{TRANSNATIONAL LITERATURE}

If transnationalism was first used in the field of migration studies, it was eventually adopted in literary studies and American Studies in the USA underpinning the transnational and cross-cultural features of ethnic writing. The transnational turn in American Studies was marked by Shelley Fisher Fishkin's presidential address to the American Studies Association in November 2004, in which Fishkin emphasised that in today's globalised world, it is necessary to look beyond one's national borders and recognise the ways in which the nation is seen from "vantage points beyond its borders" (Fisher Fishkin 23).

Despite the fact that the transnational paradigm has been discussed in the fields of sociology, anthropology and especially migration studies since the 1990s, and Fishkin's address in 2004, the work suggesting a shift from a political understanding of transnational literature towards a more aesthetic one, suggesting the modes by which "authors have responded to major historical, political, and ethical issues prompted by the globalization of literary studies" (Goyal 2017) and putting forward the transnationalism methodology that might be used in the analysis of literary works, was not published until 2017. In Transnational American Literature, Yogita Goyal argues that despite the fact that some critics have labelled transnationalism as an attempt to reinforce American exceptionalism, they have not been successful in providing an acceptable alternative as in this globalised, international, multilingual and supranational world, a return to national canons is no longer possible as the transnational turn opens up new possibilities of analysing literary works in terms of "spaces in between" (Goyal 5) encompassing "cosmopolitan travels, linguistic encounters, oceanic adventures, freedom dreams, and paranoid linkages" (6). Moreover, a transnational approach may also battle nationalisms and cultural exceptionalism by comparing and analysing the interconnectedness of different parts of the globe, their people and cultures. In short, transnationalism, 
therefore, questions borders and boundaries - may they be political, geographical or linguistic and attempts to understand the processes as they occur at contact zones as inspired by Mary Louise Pratt, signifying intercultural interaction (Pratt).

Many narratives published recently focus on the presence of migrants in what were once culturally homogenous spaces as a result of the increasingly globalised world that has accelerated the cultural, linguistic and ethnic mixing in the West, which to an extent always existed, but in comparison to past diasporic writing these contemporary stories are characterised by transnationalism, hybridity and mobile identities (Nyman 2009: 10) instead of focusing on the "fixed understandings of the issues of home, identity and nation" (10) and longing for the homeland. As Nyman points out it is "such an understanding of the interconnectedness of cultures that is at the core of the contemporary writing" (11) or to put it in the words of Schulze-Engler:

Highlighting the transnational dimensions of literature is thus not a matter of privileging "migrant" contexts of culture over all others [...] but of drawing attention to the fact that the dynamics of transnational and transcultural connections have long since become a lived reality even among the non-migrant majority of the world's population - and a ubiquitous reality shaping modern literature in "Western" and "non-Western" settings alike. (Schulze-Engler 382)

Therefore, for Schulze-Engler also, the post-colonial theoretical framework, which tends to be based on alterity industry does not suffice to be applied in the contemporary transcultural and transnational reality as culture in a globalised modernity should be understood "in terms of transnational connections and a global ecumene (Schulze-Engler 381) and as a result, the focus then shifts from international relations between cultures towards the productive communicative processes by which individuals and social groups make sense of culture in the contemporary world (Nyman 2007: 381). Similarly, Igor Maver states that "living in a diasporic space today essentially signifies the forging of a new identity and a new diasporic hybrid subjectivity" (Maver X) and that while diasporas today live in spaces of in-betweenness and are still part of the "process of construction of $U$ s vs. the Others" (ibid.), it is not quite clear how to identify Us and the Other as the binaries of post-colonialism can no longer be applied (ibid.).

However, as much as migration and mobility are undisputable characteristics of today's globalised world, the transnational migrant experience is often overly celebrated on account of simpler, cheaper and quicker communication technology and transport, simplifying and promoting unrealistic views of the processes of migration and their triumphant hybridities, which might serve as examples of the final victory over essentialist nationalist identities. While it is indisputable that diasporic 
and hybrid identities are able to challenge homogeneity and fixed identifications, it should also be taken into account that transmigrants are not always voluntary migrants, but may have migrated due to economic or environmental reasons, or as it is the case with Hemon and many of his characters, may be political migrants, asylum seekers or refugees. Although these migrants might be living fluid lives in their host countries and may be hybridizing their identities, their transitioning may not have been an easy one, but filled with feelings of displacement and trauma. It seems that one of the roles of contemporary transnational diasporic literature might be to disclose some of the more negative aspects of contemporary transnational migrant subjectivities as they are living the in-between and exilic lives marked by struggles to overcome displacement, trauma and linguistic barriers.

In light of the above, in his volume Displacement, Memory and Travel in Contemporary Migrant Writing (2017), a study of diaspora and hybridity with a focus on melancholia and displacement as well as migration and related cultural encounters, scholar Jopi Nyman argues that transnational encounters are not at all, all positive, but are often accompanied by traumatic feelings due to voluntary or involuntary exile, feelings of displacement and a sense of belonging nowhere, existing in a non-place which reoccurs in Hemon's work including in the Making of Zombie Wars, a novel in which one of the characters Bega, a disillusioned war migrant from Bosnia says: "Where do we go from nowhere?" (Hemon 2015: 12). Further, Nyman suggests that text analyses have shown that migration and up-rootedness are frequently expressed with language expressing pain and affect, demonstrating that while migration and hybridity may counter nationalisms and essentialist identities, they may also be critiques of "such forms of postcolonial discourse that celebrate them as unproblematic ways of countering hierarchies and hegemonies (Nyman 2017: 1). Here, Nyman is expanding on the idea first proposed by Paul Gilroy in his work The Black Atlantic (1993) in which the author proposes a culture that is not a single culture, but a mix of several cultures, eventually producing a new culture that transcends ethnicity and nationality and that is, extended by Nyman's study of contemporary global mobility and cultural encounters, frequently accompanied by trauma, forced exile and diaspora, displacement, and hybrid identities, and experiences of transnational migrants that are worlds away from the free cosmopolitan nomads as suggested by Steven Vertovec.

\section{ALEKSANDAR HEMON}

Aleksandar Hemon is known as an American, Bosnian and (post)-Yugoslav author and as such "actively pursues the role of a 'hyphenated' writer" (Kozmos 50), which is as shown above, a transnational characteristic in itself as it has been claimed that 
taking action and decision-making transform a migrant into a transmigrant (Blazan 38). In 1992, a few months before the siege of Sarajevo began and after having been accepted to the cultural exchange program called the International Visitor Program, Hemon came to Chicago where he soon afterwards applied for political asylum. During that time he worked as an ESL teacher where he encountered many other migrants, the experience he has employed in many of his works of fiction.

Nyman argues that the present times appear to be characterized by border-crossing movements, notable in the emergence of new migrant literatures written in the language of the host and that this increased mobility of people generates new kinds of migrant narratives and "sites for identity construction" (Nyman 2009: 15). The latter applies to Hemon since he has published texts in English, which is not his mother tongue but which he learned to perfection by fiercely studying Nabokov after he had arrived in the USA to an extent that he eventually won a nomination for the National Book Award with Nowhere Man in which he addressed displacement of migrants and migrant identity dealing with transnational encounters and border crossings (Hemon 2005). Hemon is currently a guest lecturer at Princeton University, he had his autobiography The Book of My Lives (2013) turned into a play and premiered in Sarajevo in 2017, and curated the Bookstan international festival in Sarajevo, so his professional and personal activities demonstrate that he is actively engaged in two places at the same time or that he is here and there; in Bosnia where he used to reside and in America where he is currently living. While he might have never referred to himself as a hybrid he mentioned in several interviews that he is "complicated" in the sense that he has not only one home and that he is not defined by only one nationality, which is in itself a transnational feature as shown above. In an interview with John Freeman Hemon stated that he was interested in the "multicultural presence, not just of religions, but also of languages, empires, occupiers, histories, borders, neighbors, classes" (Freeman). In an interview conducted by Irina Reyn for an online art magazine Guernica, Hemon said that he had never felt cut off from Bosnia and that he felt that he was "everywhere", had several identities, was a citizen of two countries and that he did not feel that he was writing in exile because he had always felt that he was connected to his homeland:

Well exile, as you pointed out, is not the word I would apply to myself because I'm not cut off from where I came from. I'm in touch with Bosnia in many ways, not just that I go back, but because I'm connected to the diaspora. I also participate in the American cultural and political space: from playing soccer in Chicago to voting in the American election to participating in American literature. Whereas people who may describe themselves as being in exile are nowhere, I'm actually in two places at the same time, which is different. (Reyn) 
Hemon also fits Vertovec's description of transnationalism as he identifies with a "diaspora consciousness marked by dual or multiple identification" (Vertovec 6) and continues to emphasise his fluid presence in the world:

What I think I may be typical of is a multiple identity situation. Assimilation is not an issue for me; I feel sufficiently assimilated in the United States. I'm not completely absorbed, I have not melted into the pot. My cultural instincts are satisfied by American culture. And the same thing with Bosnia. I am an American and Bosnian writer and I like to think that what happens in my books and in my life is that those two spaces overlap because I want them to overlap - I write about people who are finding ways to live in the States because their life is defined by their Bosnian experience. So this multiplicity of identities or double identities, these are not necessarily mutually exclusive and they don't create a vacuum but rather create an overlapping space where interesting things happen. This is what defines what I write and defines the other members of who you might include in that group." (Reyn)

From the above it is also clear that Hemon is a transmigrant as he has been able to maintain social, cultural and economic relations that span national borders. In addition, he considers himself as a writer operating across and beyond national boundaries in the so-called transnational and liminal Third Space as defined by Bhabha, addressing the polyvocality and in-betweenness stemming from his belief that "[c]ultures are never unitary in themselves, nor simply dualistic in the relation of Self to Other"(Bhabha 52), denouncing the binary concept.

On the basis of the above, it is therefore possible to say that Hemon is a transnational writer, a transmigrant and a member of the diaspora. However, while it seems that his life is a triumph over his initial involuntary exile enabled by the processes of globalisation and transnationalism, in his work rather than celebrating exile and in-betweenness, Hemon exposes the issues that migrants deal with related to the notions of home and identity, trauma, displacement and feelings of belonging nowhere while at the same time assuming hybrid identities in the space of in-betweenness. In his words, he writes "about people who are finding ways to live in the States because their lives are defined by their Bosnian experience".

The concept of hybridity is at the core of post-colonial theory and in its basic sense denotes intercultural transfer and the identities that evolve during this process and can thus be applied in transnational and transcultural studies. Homi Bhabha views hybridization as a process that is happening in the Third Space of enunciation where identity is reconstructed, negotiated and translated and which involves an "estranging sense of the relocation of the world - the unhomeliness" that is "the condition of extra-territorial and cross-cultural initiations" (Bhabha 9) and as a hybrid is imagined through spatial terms, Bhabha links hybridity with diaspora 
whereby "To be unhomed is not to be homeless" (9). Similarly, Nyman argues that diaspora is a hybrid space where transnational flows may remould identities so that diasporic identities are essentially hybridized identities, moulded in a space that is in-between affected by issues of home and belonging (Nyman 2009: 22) and the hybrids' potential is that they are able to transverse cultures and difference.

\section{THE MAKING OF ZOMBIE WARS}

The Making of Zombie Wars (2015) portrays migrants and their struggles to integrate, but also the building of cultural bridges and processes that foster cultural understanding between diaspora and the host, promoting cultural fluidity. New identities and subjectivities are imagined in the novel and fixed notions of home and belonging are questioned. The main character is a 33-year old wannabe screenplay writer Joshua Levin, who has a Japanese-American girlfriend Kimmy, is of Jewish descent and works as a teacher of English as a second language to a group of seven dislocated migrants from Eastern Europe, one of whom is Ana, a migrant from Sarajevo that Joshua falls in love with. In addition, in his screen-writing class Joshua meets Bega, who is also a traumatised and displaced migrant from Sarajevo. The novel's settings of the ESL classroom and the screen-writing class are in line with Igor Maver's observation that the immigrants' reintegration and (re)construction of identity and cultural adjustment after the initial trauma caused by their sudden displacement from their original cultural and linguistic setting is facilitated by communication through language and other means of creative-expression (Maver 20). Maver's position also holds true for Hemon himself, who reintegrated and reconstructed his identity by teaching ESL initially, moving on to writing.

Another example of cultural fluidity and intertwining cultural practises is the way with which Hemon brings together American (Western) music and Yugoslav (Balkan) music as Bega is a fan of both, so Led Zeppelin, Bob Dylan, Pantera and Nirvana are mentioned alongside the TV show that most of us who grew up in former Yugoslavia remember - "The Top List of Surrealists". Bega therefore displays a transcultural mixing of cultures, the intertwining of the Balkans and the West, of the periphery and the centre, which are no longer binary opposites. This is in line with Stuart Hall's understanding of the role of music in "Cultural Identity and Diaspora" where he shows how reggae music mediates between Jamaican and African identity (Hall 223). As Hemon uses music to demystify the poor and isolated Balkans and according to Blazon demystification is one of the key principles of transmigrant literature (Blazon 44), it can be further argued that the novel is an example of transnational fiction. 
Furthermore, Joshua's ESL classroom, otherwise a recurrent theme in Hemon's work is an example of a contact zone where mixing of cultures takes place and is a hybrid Third Space since Teacher Josh is teaching the immigrants how to speak the language of their host country and is at the same time learning about their respective cultures and homelands. The ESL classroom may therefore be understood as a microspace, exemplifying the interconnectedness of cultures that Schulze-Engler refers to when stating that transnational connections are also a reality amongst the non-migrant majority as well as Bhabha's Third Space of enunciation, where fixed meanings are reconstructed into new ones, comes to life. When Joshua gives his students an assignment to write about their respective hometowns, he hears about places such as Vitebsk, Moscow, Kazakhstan and Sarajevo, which Ana describes as it was before the war: "people greeted one another on the street; the youth danced all night; there was a linden tree smelling sweetly and quaintly right under her window" (Hemon 2015: 45). Here, Hemon again demystifies Sarajevo by mentioning the city's positive characteristics. In the novel Hemon created several scenes featuring Bhabha's Third Space of in-betweenness. For example, Joshua is invited to Ana's party in the apartment building wittily called the Ambassador as it is mostly populated by migrants and functions as a transnational Third Space. As Joshua is on his way up to Ana's apartment and he listens closely for the sounds on the other side of doors, he can hear "a radio gibbering in an obscure language" and "Mexican oompah-oompah music" (75), signalling hybrid spaces. The party is a further example of a transnational space where Joshua learns about the migrants' food, decorating style and sense humour. At the party Hemon puts Joshua in the place of a migrant looking into the centre from the periphery as he is the only American surrounded by migrants who are mostly from Bosnia and where he is the one who needs to adjust as they are speaking in a foreign language and eating food that he had never seen before:

"What am I eating?" he asked her. She pointed at things and named them in Bosnian and he kept trying to repeat the words. There was no hope-Bosnian sounded like Hebrew spoken by someone with a debilitating speech impediment..."(84).

Here, Hemon reverses the hierarchy, the hegemon becomes the subaltern, the post-colonial Us assumes the role of the Other, even if only for the duration of the party. This is in accordance with another characteristic of migrant writing that by questioning the fixed notions of home and identity, it remaps cultural identities for everyone involved:

It is argued instead that migration changes individual and group identities, affiliations and cultural attitudes and practices, among the mobile population and the "hosts". As soon as it is recognized that cultures are fluid and temporary social constructions, made and remade over time - [James] Clifford's translocal 
culture - it is apparent that movement involves the remapping of cultural identities for all those involved. (McDowell 210).

Cultural identities of all those involved are remapped as Joshua is othered at this party not only by not knowing the food that is served, by not understanding the language, but also by not being familiar with the culture. As the guests are telling each other jokes in Bosnian and everyone but Joshua is laughing and Ana makes an attempt to translate one of them, she finally says: "Very hard to translate" and indeed Joshua laughed, "but his laughter was devoid of the abandon he'd witnessed in the Bosnian" (84). Hemon uses this situation to show the trauma and displacement as after the translation of the joke to Joshua was not successful the real migrants "sat in silence for a while" and "the mistranslated joke had reminded them how sad and displaced they really were" (85). The party is an example of a translocal space as migrants are making a new place their home and are engaging in reciprocal links between themselves and a representative of the host country, who in this case, is Joshua as the only host country national at the party. In line with transnationalism cultures are porous and open to influences. While there is still Us and the Others, these relations are not fixed, but fluid as Joshua is othered.

In line with McDowell's observation above, in Hemon's novel it is therefore not only the migrants who undergo a process of transformation, but Joshua as the representative of the host, hegemonic culture, also transforms as he begins to understand the migrant better. For example, when he talks about Ana, the Bosnian migrant whom he is becoming infatuated with, he at some point begins to understand that the shortness of her skirt does not "signify promiscuity-contrary to the consensual interpretation to other male teachers-but a kind of nostalgia" (46) and that this was what she used to wear when she was happy, when she used to live a normal life back in her hometown of Sarajevo.

Next, displacement in Nymans's terms is shown on several occasions throughout the novel. For example, Bega is on an occasion called 'Vega' by the screenplay-writing teacher:

"Bega," Bega said. "I am Bega. As I was before" (17). When Bega says 'As I was before' this suggest that he divides his life in 'before exile' and 'after exile', or 'before displacement' and 'after displacement' and that by someone not pronouncing his name correctly, he is automatically put in an inferior position in accordance to Nyman's understanding above. He is othered. In fact, Bega is unlike Ana, a character who is in exile, longing for belonging to his homeland. The novel contains several allusions to the 'before' and 'after' that Bega makes: "But the before was no longer available, nor would it ever be..." (34), or "The clothes belonged to the before, and he had no attire for the after" (40), suggesting displacement. When Bega is asked to say something about his screenplay he reveals the exile baggage: 
"It's basically love story," Bega said. "Man is from Sarajevo. He was happy there. He was young, he had rock group, had women. War came. He is refugee now. He goes to Germany. They are Nazis there. He works like security in disco, plays his guitar only for his soul. He drinks, remembers Sarajevo, writes blues songs. Comes 1997, Nazis throw him out. He goes back to Sarajevo, but nothing is same. Heartbreak." (18) and then: "Man has no more friends in Sarajevo. Half of his group is dead, other half everywhere. Women have husbands. Everybody talks about the war all the time. He says, Fuck it! and goes to America - country of Dylan and Nirvana and best basketball. But he lost his soul. And American women are all feminists-" (18). Here Hemon quite clearly gives the reader an insight into the soul of a transnational migrant, who knows about American music as a result of globalisation and "mediascapes" to use Appadurai's terminology (Appadurai), who can go back to his home country, but feels displaced there also as the homeplace has changed and his friends are also "everywhere". In accordance with Nyman, the language Bega uses expresses pain and affect.

The migrants in Hemon's novel all had lives before coming to the US and they were a somebody. The ESL class that Joshua teaches, for example, is composed of Captain Ponomarenko who used to be an officer of the KGB, Fyodor was a rocket scientist and a Bosnian woman Ana used to study medicine until the war broke out. By coming to America their 'before' is no longer and they are reduced to role play in Joshua's ESL class.

Nyman in his book Displacement, Memory and Travel in Contemporary Migrant Writing (2017) writes that as migrants experience displacement differently from one another and have different memories of their pre-exile lives, they also integrate differently into their new society and the degree to which they become attached to their new culture also varies (ibid.). This is shown in Hemon's novel by Ana on one hand, who is Joshua's best student, has plans for her future in America, while the other students in the class and Bega who are all more on the outside looking in. But Ana's transitioning is not without difficulties as her identity is reduced to that of an ESL student as when she invites Joshua to her party, before answering he corrects her English, immediately putting her in an inferior, peripheral position:

\footnotetext{
"There is a party," she said. A dimple in her left cheek appeared and disappeared without anything else in her face changing.

"A party,"Joshua said.

"Saturday in the evening."

"Saturday evening." (Hemon 2015: 50)
}

But Ana wants the future and symbolically this desire to transform is expressed by her being the only one to use the Future Perfect Tense after they have studied 
it in class and as she says to Joshua at some point, she wants to improve her English because she wants to find a better job. Her affair with Joshua, a local, is her way of negotiating hybridity, the stairwell, or the Third Space, while her marriage to Esko, a Bosnian traumatized special forces veteran, symbolizes her ties with Bosnia. While their apartment symbolizes Bosnia, her home country, which she symbolically describes as: "crazy messy" (81), spending the night with Joshua in his apartment symbolizes America, the host country, while the ESL classroom represents a hybridized space. The in-betweenness and hybridity in the novel are also signalled by the way that the past perpetually enters the present, especially by way of memories about the homeland, which is in line with what Nyman argues namely that identity is fluid and transitional and based on fragments of place memories, on the migrants' wishes and past experiences. Similarly, David Morley positions that migrants' sense of home, which is essential to one's identity is more than just geography and is as such not always place-related, but may mean more symbolic objects, which may help the migrant to connect to home while living in the land of the Other (Morley 44). In this way migrants' recollections of their home countries appear throughout the novel, an example is Bega's Bosnian carpet in his apartment as well as the ethnic food that the migrants enjoy at the party.

Further evidence that the novel fits the characteristics of transnational writing is that in accordance with Goyal's claim that while exile and expatriation have always been central to the study of modernism, it is only a transnational approach that has made it possible to expand on these themes and explore how "writers imagine and represent other worlds in relation to their own" (Goyal 10) and in Fishkin 's words how the nation, in her case American, is seen from "vantage points beyond its borders" (Fisher Fishkin 23), through his characters in The Making of Zombie Wars, Hemon gives several insights into how the author and his immigrant characters see America, which is often as vain, populist and generally not very intelligent: "Tell me why is that," Bega said, "last eight presidents have simple names: Johnson, Nixon, Ford, Carter, Reagan, Clinton, two with Bush. You need to have Washington, Roosevelt, and Eisenhower, and then something happened. You can't elect your president with complicated name anymore. Idiot voters have to be able to spell fucking name" (Hemon 2015: 23). In fact, the book features many such observations, for example, Captain Ponomarenko "still resented the fact that America, the land of limp imbeciles - amply represented by Teacher Josh-somehow managed to win the Cold War" (43) and the students brought up the Iraqi war every lesson "to expose the external rottenness of America's imperialist soul" (43). 


\section{CONCLUSION}

Hemon might be living an almost idyllic transnational existence by being personally (he is married to an American), professionally and politically involved in Bosnia and the USA, his characters in The Making of Zombie Wars are still transitioning into becoming comfortable hybrid identities. However, the novel features transnational settings as Third Spaces ranging from the ESL class to a party featuring guests of various ethnicities, which Hemon uses to show the relations as they unfold when cultures come into contact, interact, intertwine and affect each other. If past migrant writing concentrated on the migrants' longing for their lost homelands, Hemon's diasporic writing emphasises the desire to belong while questioning the fixed notions of home, and identity. But as shown above, the life of the diaspora should not be glorified as it has been by some critics who neglected the fact that the current era of transnational migrations does not only include voluntary migrants or "wanderers" as Bhabha refers to them (Bhabha 315), but also refugees and political migrants who populate the works of Aleksandar Hemon.

\section{BIBLIOGRAPHY}

Bhabha, Homi. The Location of Culture. Routledge, 1994.

Fisher Fishkin, Shelley. "Crossroads of Cultures: The Transnational Turn in American Studies:

Presidential Address to the American Studies Association, November 12, 2004.” American Quarterly, Vol. 57, No. 1, pp. 17-57.

Freeman, John. "How the Writer Uses Humour.", July 28, 2016, https://lithub. com/how-the-

writer-uses-humor-aleksandar-hemon/

Gilroy, Paul. The Black Atlantic: Modernity and Double Consciousness. London: Verso, 1993.

Hall, Stuart. "Cultural Identity and Diaspora." In: Contemporary Postcolonial Theory: A Reader, edited by Padmini Mongia, pp- 110-21, London: Arnold, 1996.

Hemon, Aleksandar. Nowhere Man. Picador, 2005.

Hemon, Aleksandar. The Book of My Lives. Picador, 2013.

Hemon, Aleksandar. The Making of Zombie Wars. Picador, 2015.

Kosmos, Iva. Mapping of Exile in Works of Post-Yugoslav Authors,

Diss. University of Zagreb, 2015.

Kuorrti, J. and Jopi Nyman (Ed.) Reconstructing Hybridity: Post-Colonial Studies in Transition. Rodopi, 2007.

McDowell, Linda. Gender, Identity and Place. University of Minnesota, 1999. 
Michael D. Levin "Flow and Place: Transnationalism in Four Cases." Anthropologica, XLIV, pp. 3-12, 2002.

Morley, David. Home Territories: Media, Mobility and Identity. London: Routledge, 2000.

Nyman, Jopi. Displacement, Memory and Travel in Contemporary Migrant Writing. Amsterdam: Rodopi, 2017.

Nyman, Jopi. Home, Identity and Mobility in Contemporary Diasporic Fiction. Amsterdam:

Rodopi, 2009

Resek, Carl (Ed). War and the Intellectuals, Essays by Randolph S. Bourne 19151919. New York: Harper, 1964.

Reyn, Irina. “Exile on Any Street.”, February 1, 2010. https://www.guernicamag. com/not_melted_into_the_pot/

Schulze-Engler, Frank. 2000. "Literature in the Global Ecumene of Modernity: Amitav

Ghosh's The Circle of Reason and In an Antique Land." In Antor and Stierstorfer, pp. 373-96, 2000.

Maver, Igor (Ed.). Diasporic Subjectivity and Cultural Brokering in Contemporary Post-Colonial Literatures. Lexington Books, 2009.

Vaughan, Leslie. J. "Cosmopolitanism, Ethnicity and American Identity: Randolph Bourne's

“Trans-National America.” Journal of American Studies, Vol. 25, No. 3, pp. 443-459. Goyal, Yogita. (Ed.) The Cambridge Companion to Transnational American Literature.

Cambridge University Press, 2017.

Pratt, Mary L. "Arts of the Contact Zones." Profession, Modern Language Association, 1991.

https://www.jstor.org/stable/25595469

Nina Bostič Bishop

University of Ljubljana Nina.bostic-bishop@fdv.uni-lj.si

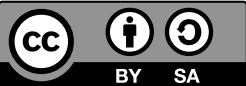




\section{Transnacionalizem in hibridne identitete $\mathrm{v}$ delu The Making of Zombie Wars Aleksandra Hemona}

Transnacionalnost je trenutna realnost in je posledica globalizacije, ki se odvija z največjo hitrostjo doslej zaradi razvoja tehnologije, transporta in telekomunikacij. Vsesplošne migracije, bodisi prostovoljne ali prisilne, so značilnost sodobnega sveta, vendar transmigranti ne živijo v izgnanstvu na način, ki je bil običajen v preteklosti, ko je veliko migrantov hrepenelo po bivši domovini. Transmigranti živijo v vmesnem prostoru med državo gostiteljico in domovino, kjer se mešajo kulture. Čeprav literatura ta vmesni prostor pogosto idealizira, mnogi transmigranti živijo z občutji izgube, razseljenosti in travme. Članek umešča bosansko-ameriškega avtorja Aleksandra Hemona v transnacionalno književnost $\mathrm{v}$ diaspori in išče prvine transnacionalizma $\mathrm{v}$ avtorjevem življenju in njegovem romanu The Making of Zombie Wars. Članek analizira hibridne identitete, ki nastopajo v romanu in se borijo s posledicami razseljenosti, travm in mobilnosti, sledeč teorijam Homi Bhabhe in Jopi Nymana. Članek razkriva procese, kot se odvijajo v teh vmesnih prostorih.

Ključne besede: Aleksandar Hemon, transnacionalnost, hibridnost, književnost v diaspori, razseljenost, The Making of Zombie Wars 